\title{
Risk Management Analysis Using COBIT 4.1 at Vehicle Testing Management Information System
}

\author{
http://dx.doi.org/10.28932/jutisi.v7i1.3419 \\ Riwayat Artikel \\ Received: 19 Februari 2021 | Final Revision: 14 Maret 2021 | Accepted: 16 Maret 2021
}

\author{
Resad Setyadi $^{\bowtie \# 1}$, Septian Anggoro ${ }^{\# 2}$ \\ \#Program Studi Sistem Informasi, Fakultas Informatika \\ Institut Teknologi Telkom Purwokerto \\ DI Panjaitan No 128 Purwokerto, Central Java \\ ${ }^{1}$ resadeittelkom-pwt.ac.id \\ 217103040@ittelkom-pwt.ac.id
}

\begin{abstract}
The role of information technology in an organization is growing so fast. Vehicle Testing of Management Information System (VTMIS) is a system that uses information technology to serve users in motor vehicle administration in the Banyumas transportation service area. VTMIS at the Banyumas Transportation Department is an integrated information system for the motor vehicle testing process starting from the registration process, levy payment, and vehicle testing. The purpose of this study is to analyze the risk management at VTMIS in Banyumas Transportation Department using Control Objective for Information and Related Technology (COBIT 4.1) domain Plan and Organize (PO) 9. COBIT 4.1 is a framework for analyzing and ensuring information technology aligns with business management by calculating maturity levels. The data analysis results from the PO9 domain show that VTMIS risk management has a maturity level of 3.46. The maturity level of VTMIS at the Banyumas Transportation Department is at level 3, namely defined, meaning that procedures are in a position of standardization, documentation, and individual communication. The recommendation for VTMIS at the Banyumas Transportation Department needs to carry out risk management in a structured, massive and integrated manner.
\end{abstract}

Keywords - control objective for information and related technology; maturity level; plan and organize; risk management; vehicle testing of management information system.

\section{Pendahuluan}

Information technology (IT) is essential for government institutions, especially during the COVID-19 pandemic situation [1]. Information technology (IT) is necessary for all work and human mobility activities [2]. IT provides many positive benefits, including solutions for companies in operations and business, enabling the company to grow, making it competitive with other companies [3], [4]. However, IT also negatively impacts virus attacks, data hacking, and theft of confidential data. One government institution that is making the most of IT's benefits is the police institution [5]. The motorized vehicle administration service unit in the police is one of the public service units that make maximum use of IT to provide community services.

The police institution in the Banyumas area, Central Java, collaborates with civilian government institutions to try to make maximum use of the IT function in administrative services to operate the motorized vehicle testing system. The service system is called Vehicle Testing of Management Information System (VTMIS). VTMIS is an integrated motorized vehicle system owned by the police institution that functions for administrative management related to the motor vehicle testing process, starting from the registration process, paying levies, and testing vehicles in the Banyumas transportation service area. Because the police service unit is so essential, it is necessary to have IT management, supervision, and maintenance in this police unit. However, the maximum use of IT by VTMIS needs to pay attention to risk management which must run simultaneously when the system is also operating.

Regarding risks or threats that occur in operations, the police, through VTMIS hopes to get input, in this case, a solution to reduce the level of the risk, to overcome risks that often occur and risks that rarely happen in the company. Therefore, the police need Information Technology 
Governance (ITG) to mitigate and reduce the risk that has already occurred [6]. With ITG based on risk analysis, the police institution will have strong IT governance and support their business strategy [7]. From the explanation of the research background, two research questions guide the implementation of the research.

RQ1: What is the risk management maturity level in terms of the Plan and Organize Domain in VTMIS?

RQ2: What recommendations are given based on the risk management maturity level in VTMIS?

\section{LITERATURE REVIEW}

Control Objective for Information and Related Technology (COBIT) 4.1 is a medium for measuring IT governance. Use of COBIT 4.1 for VTMIS risk management analysis of police institutions, especially the Plan and Organize (PO) domain [8], [9]. IT governance aligns IT investment with business strategy and eliminates the risks of using IT [10]. IT governance is part of corporate governance that focuses on IT management in organizations, including IT system performance and risk management [11]. COBIT 4.1 is useful for managers, audiences, and IT users in the form of a procedural sequence of action steps to maximize the benefits of using IT [12]. COBIT 4.1 mission is to conduct research, development, publishing, promotion of papers, updating the sequence or provisions of an IT Control Purpose. Meanwhile, the vision of COBIT 4.1 is to make CO-BIT a model for IT control and management [13]. The following are the 4 Domains of the COBIT 4.1 variable:

1. Plan and Organize (PO)

2. Acquire and Implementation (AI)

3. Deliver and Support (DS)

4. Monitoring and Evaluation (ME).

\section{Plan and Organize (PO)}

This domain contains strategies and IT identification tactics that can best contribute to achieving the organization's business goals to become a good organization with the right technology infrastructure. The domain has 11 indicators as in table I:

TABEL I

INDICATOR OF PLAN AND ORGANIZE

\begin{tabular}{|l|l|}
\hline Indicator & \multicolumn{1}{|c|}{ Describe } \\
\hline PO1 & Determine a strategic information technology plan. \\
\hline PO2 & Define the information architecture. \\
\hline PO3 & Specify technology direction. \\
\hline PO4 & Define IT organization and relationships. \\
\hline PO5 & Manage investment in information technology \\
\hline PO6 & $\begin{array}{l}\text { Communicate management objectives and } \\
\text { direction. }\end{array}$ \\
\hline PO7 & Manage human resources. \\
\hline PO8 & Manage quality \\
\hline PO9 & Assess risk. \\
\hline PO10 & Manage the project. \\
\hline
\end{tabular}

\section{Acquire and Implement (AI)}

This domain contains IT strategy realization, identification of IT solutions, building IT, and integration of IT into business processes. This domain has 7 indicators, as in table II:

TABEL II

INDICATOR OF ACQUIRE AND IMPLEMENTATION

\begin{tabular}{|l|l|}
\hline Indicator & \multicolumn{1}{c|}{ Describe } \\
\hline AI1 & Identifies automatic solutions \\
\hline AI2 & Acquire and maintain application software \\
\hline AI3 & Acquire and maintain technology infrastructure \\
\hline AI4 & Develop and maintain IT procedures \\
\hline AI5 & Meets IT Data Sources \\
\hline AI6 & Managing change \\
\hline AI7 & $\begin{array}{l}\text { Installing and accrediting systems and their } \\
\text { changes }\end{array}$ \\
\hline
\end{tabular}

\section{Delivery and Support (DS)}

This domain serves to provide security process services, business continuity aspects, and provision of training. The domain has 13 indicators, as in table III:

TABEL III

INDICATOR OF DELIVERY AND SUPPORT

\begin{tabular}{|l|l|}
\hline Indicator & \multicolumn{1}{c|}{ Describe } \\
\hline DS1 & defines and manages service levels \\
\hline DS2 & manages third party services \\
\hline DS3 & manages performance and capacity \\
\hline DS4 & ensures continuous service \\
\hline DS5 & ensures system safety \\
\hline DS6 & identifies and allocates costs \\
\hline DS7 & educates and trains users \\
\hline DS8 & manages service and incidents \\
\hline DS9 & manages configuration \\
\hline DS10 & manages problems \\
\hline DS11 & manages data \\
\hline DS12 & manages Facilities \\
\hline DS13 & manages operations \\
\hline
\end{tabular}

\section{Monitor and Evaluation (ME)}

This domain functions to periodically assess IT processes based on the quality and suitability of control requirements. The domain has 4 indicators, as in table IV:

TABEL IV

INDICATOR OF MONITOR AND EVALUATION

\begin{tabular}{|l|l|}
\hline Indicator & \multicolumn{1}{c|}{ Describe } \\
\hline ME1 & supervises and evaluates IT performance \\
\hline ME2 & supervises and evaluates internal controls \\
\hline ME3 & ensures fulfillment of external needs \\
\hline ME4 & provides IT governance \\
\hline
\end{tabular}


Based on the description of the four COBIT 4.1 domains, the PO9 domain serves as the main tool for describing risk management assessments in the Banyumas Police VTMIS application. Figure of the overall COBIT 4.1 Framework as in Figure 1:
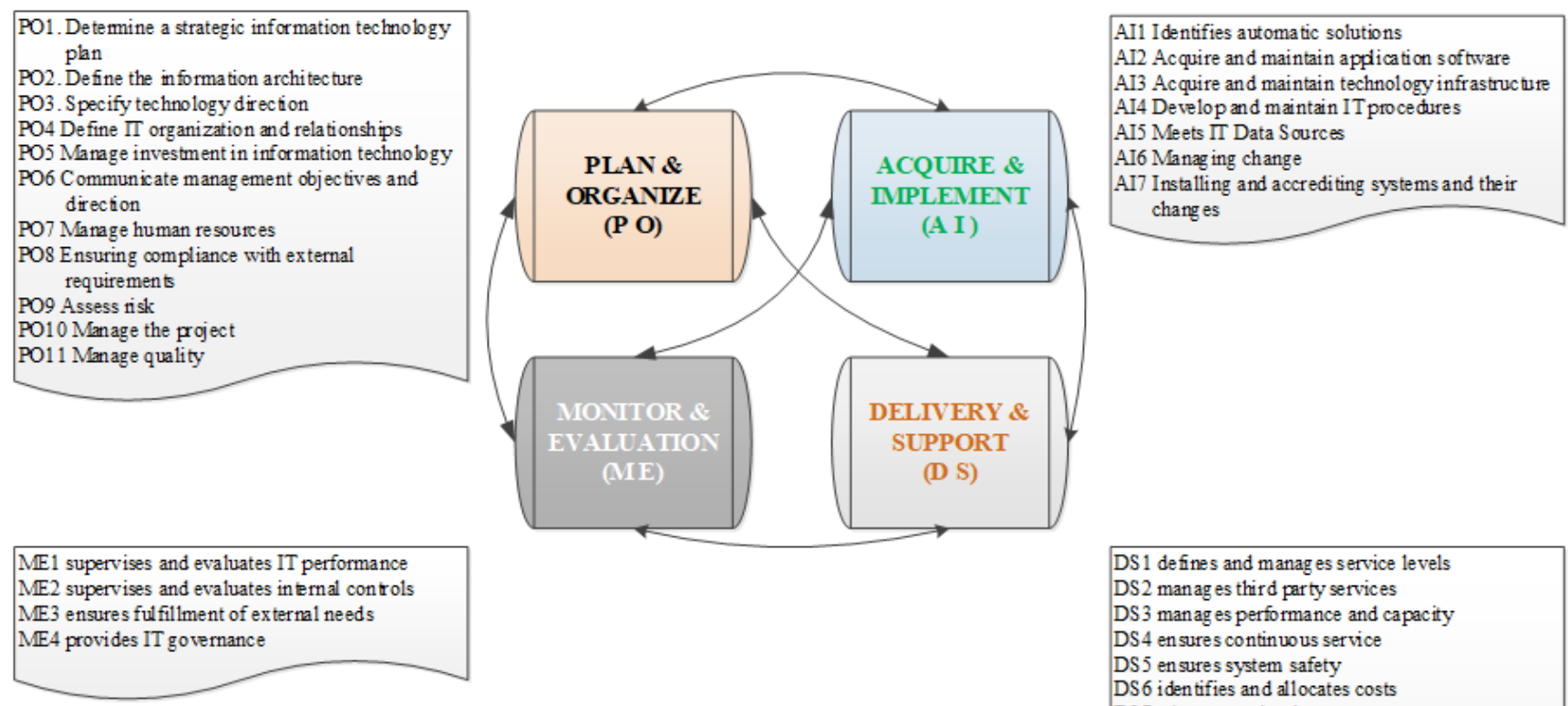

Figure 1. COBIT 4.1 Framework

\begin{tabular}{|l|}
\hline DS 1 de fines and manag es service levels \\
DS 2 manag es third party services \\
DS 3 manag es performance and capacity \\
DS 4 ensures continuous service \\
DS 5 ensures system safety \\
DS 6 identifies and allocates costs \\
DS 7 educates and trains users \\
DS 8 manag es service and incidents \\
DS 9 manag es configuration \\
DS 10 manages problems \\
DS11 manages data \\
DS 12 manages Facilities \\
DS 13 manages operations \\
\hline
\end{tabular}

\section{A. Maturity Level of COBIT 4.1}

COBIT 4.1 has a maturity level to control IT processes using the assessment method to assess their IT processes on a scale from 0 to 5 . The maturity level of COBIT 4.1 in table $\mathrm{V}$ :

TABEL V

MATURITY LEVEL OF COBIT 4.1

\begin{tabular}{|l|l|}
\hline Value & \multicolumn{1}{c|}{ Describe } \\
\hline $0-0.5$ & $0:$ Not Existent \\
\hline $0.51-1.50$ & $1:$ Initial \\
\hline $1.51-2.50$ & 2: Repeatable but Intuitive \\
\hline $2.51-3.50$ & 3: Defined Process \\
\hline $3.51-4.50$ & $4:$ Managed and Measurable \\
\hline $4.51-5.00$ & 5: Optimized \\
\hline
\end{tabular}

\section{B. Compliance Value}

The measurement technique in the maturity level uses several questions, and each question has a group of appropriateness using a standard assessment as shown in table VI:
TABEL VI

COMPLIANCE VALUE

\begin{tabular}{|c|l|c|}
\hline Scale & Statement of Compliance Value & $\begin{array}{c}\text { Compliance } \\
\text { Value }\end{array}$ \\
\hline 1 & Not true & 0 \\
\hline 2 & Little truth & 0.33 \\
\hline 3 & Most of it is true & 0.66 \\
\hline 4 & Correct & 1 \\
\hline
\end{tabular}

The research method process takes steps starting from the research procedure, determining and taking data samples, data analysis, discussion, and concluding. The analysis conducted is descriptive and inferential maturity level analysis, limitations, and research recommendations supported by other studies. 


\section{METHOD}

Figure 2 describe the research procedures:

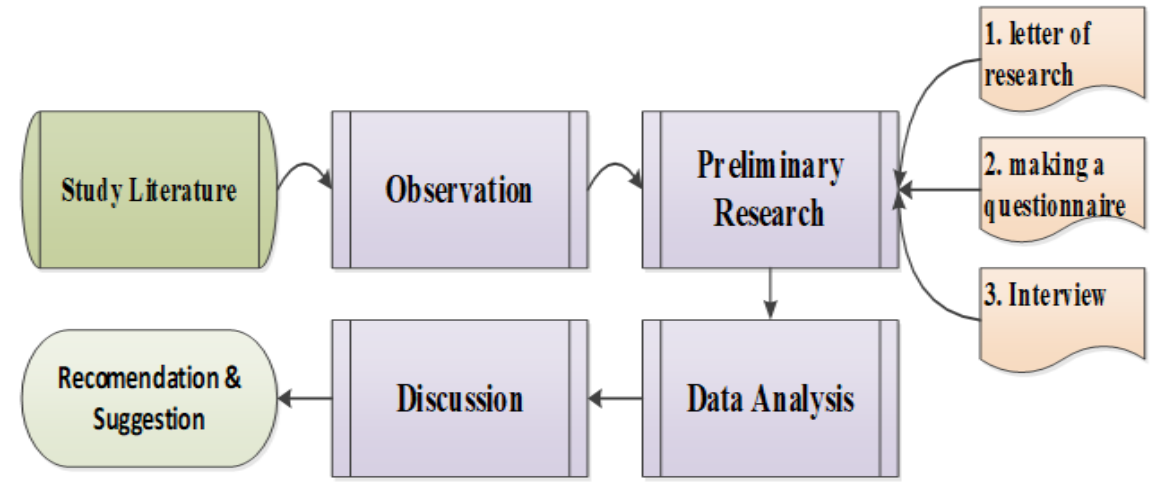

Figure 2. The Research Procedure

\section{A. Study Literature}

It requires an understanding of the maturity level of risk management for the COBIT 4.1 at P09 domain as a reference for assessing digital bus transportation services.

\section{B. Observation}

It made initial observations by conducting a questionnaire instrument test and interviewing several VTMIS staff members before distributed the revised questionnaire.

\section{Preliminary Research}

It is conducted by obtaining research approval for the research object, making revisions to the questionnaire, becoming the primary research questionnaire, and conducting interviews with several new respondents. The Instrument test is determining the validity and reliability of the questionnaire questions.

For the validity test, the product-moment correlation technique to test validity. The validity test is useful for knowing whether the measuring instrument measures what needs to be measured. Product is implementing method by correlating each question with the total score for each variable. Correlation figures obtained statistically must be compared with the critical statistics of the correlation table of $\mathrm{r}$ values with a significant level of $95 \%$. $r$ count $>r$ table means that the data is substantial (valid) and suitable for hypothesis testing. And vice versa if $r$ count <from $r$ table indicates, the information data is not significant (invalid) and will not be included in testing the research hypothesis.

$$
r_{\text {count }}=\frac{n\left(\sum X Y\right)-\left(\sum X\right)\left(\sum Y\right)}{\sqrt{\left(n \sum X^{2}\right)-\left(\sum X\right)^{2}\left(n \sum y^{2}-\left(\sum Y\right)^{2}\right)}}
$$

$\mathrm{r}_{\text {count }}$ : correlation coefficient between $\mathrm{X}$ and $\mathrm{Y}$ variables $\mathrm{N}$ : number of respondents

$\Sigma_{\mathrm{X}}$ : total scores of the items

$\Sigma_{\mathrm{Y}}$ : total scores of questions

$\Sigma_{\mathrm{X}}^{2}$ : total score squares of the items

$\Sigma_{Y^{2}}$ : total score of the squares of the items

The reliability test determines whether the data collection tool showed accuracy, stability, or consistency in expressing individuals specific symptoms, even though it did at different times. Reliability test is on statements that are already valid. This test uses the Cronbach alpha technique because the answer value consists of a range of deals with the larger alpha coefficient. Reliability means trustworthy "That is, the instrument can give the right results.

$r_{\text {instrument }}=\left(\frac{n}{n-1}\right)\left(1-\frac{\sum s_{i}{ }^{2}}{\sum s_{t}{ }^{2}}\right)$

$r_{\text {instrument }}$ : reliability of instrument

$\mathrm{n}$ : number of questions

$\mathrm{S}_{\mathrm{i}}^{2}$ : variance of item

$\mathrm{s}_{\mathrm{t}}^{2}$ : total variance

\section{Data Analysis}

It analyzes the data using COBIT 4.1 specifically for the domain in P09 to determine the maturity level of risk management.

It needs to normalize value data to calculate the maturity level of the P09 domain. The process is normalizing value from each group by dividing each compliance value by the total compliance value. The second step gets each level contribution value by multiplying the respective compliance 
values to the individual level values. The calculation of contribution value is the maturity level index.

$\mathrm{NV}=\frac{\mathrm{CV}}{\mathrm{TCV}}$

NV: Normalize data Value

$\mathrm{CV}$ : Compliance Value

TCV: Total Compliance Value

$\mathrm{CONV}=\frac{\mathrm{CV}}{\mathrm{LV}}$

CONV: Contribution Value

CV: Compliance Value

LV: Level

$\mathrm{ML}=\sum \mathrm{CONV}$

ML: Maturity Level

CONV: Contribution Value

\section{E. Discussion}

It needs to clarify by comparing the results of research data analysis by conducting discussions by comparing them with previous research by experts regarding risk management and VTMIS applications.

\section{F. Recommendation and Suggestion}

It concludes the discussion results and makes positive recommendations for VTMIS. It also provides suggestions for ongoing research for other researchers who are interested in continuing this research.

\section{RESULT AND DISCUSSION}

The first step in data analysis is to identify the respondent profile. In table VII, questionnaire respondents in the VTMIS environment have various education levels, work types, computer skills.

TABEL VII

THE RESPONDENT PROFILE

\begin{tabular}{|c|c|c|}
\hline Standard & Indicator & $\%$ \\
\hline Job position & Management of VTMIS & 22 \\
& staff of VTMIS & 78 \\
\hline \multirow{3}{*}{ Education level } & Magister & 22 \\
& Bachelor & 50 \\
& Associate degree & 28 \\
\hline \multirow{3}{*}{ Computer Skill } & Good & 12 \\
& Enough & 50 \\
& Less & 38 \\
\hline
\end{tabular}

\section{A. Validity Test}

The data obtained and inputted into the validity formula for the validity test instrument results, as shown in Table VIII;
TABEL VIII

VALIDITY TEST P09 (LEVEL 0-5)

\begin{tabular}{|c|c|c|c|c|}
\hline Level & $\begin{array}{c}\text { N of } \\
\text { Items }\end{array}$ & $\begin{array}{c}\text { Average } \\
\mathbf{r}_{\text {count }}\end{array}$ & $\mathbf{r}_{\text {table }}$ & result \\
\hline 0 & 3 & 0.870 & 0.561 & Valid \\
\hline 1 & 7 & 0.880 & 0.573 & Valid \\
\hline 2 & 3 & 0.871 & 0.561 & Valid \\
\hline 3 & 6 & 0.879 & 0.570 & Valid \\
\hline 4 & 11 & 0.902 & 0.585 & Valid \\
\hline 5 & 7 & 0.883 & 0.573 & Valid \\
\hline
\end{tabular}

B. Reliability Test

The results of the reliability test were coming from the research data. It input into the reliability formula as in Table IX:

TABEL IX

RELIABILITY TEST P09 (LEVEL 0-5)

\begin{tabular}{|c|c|c|}
\hline $\begin{array}{c}\text { Cronbach } \\
\text { Alpha }\end{array}$ & $\begin{array}{c}\text { Cronbach Alpha based on } \\
\text { standardized items }\end{array}$ & $\begin{array}{c}\text { N of } \\
\text { items }\end{array}$ \\
\hline .946 & .932 & 3 \\
\hline .961 & .951 & 7 \\
\hline .945 & .941 & 3 \\
\hline .946 & .942 & 6 \\
\hline .963 & .960 & 11 \\
\hline .947 & .945 & 7 \\
\hline
\end{tabular}

\section{Maturity Level Test}

The maturity level test results of risk management at VTMIS using the COBIT 4.1 domain of P09 (Assess risk) as in Table X; Table XI; Table XII; Table XIII; Table XIV; Table XV.

TABEL $X$

COMPLIANCE LEVEL 0

\begin{tabular}{|c|c|c|c|c|c|c|}
\hline \multicolumn{2}{|c|}{ Maturity Level 0} & \multirow{2}{*}{ 0 } & \multirow{2}{*}{0.33} & \multirow{2}{*}{0.66} & \multirow{2}{*}{1} & \\
\hline No & Statement & & & & & \\
\hline 1 & $\begin{array}{l}\text { risk assessment } \\
\text { does not occur. }\end{array}$ & 3 & 1 & 2 & 12 & 13.05 \\
\hline 2 & $\begin{array}{l}\text { the organization } \\
\text { does not consider } \\
\text { security } \\
\text { vulnerabilities }\end{array}$ & 6 & 1 & 2 & 9 & 10.65 \\
\hline 3 & $\begin{array}{l}\text { risk management } \\
\text { is not relevant to } \\
\text { acquiring IT } \\
\text { solutions }\end{array}$ & 3 & 1 & 2 & 12 & 13.65 \\
\hline & Total & & & & & 37.95 \\
\hline & Compliance Value & & & & & 12.65 \\
\hline
\end{tabular}

TABEL XI

COMPLIANCE LEVEL 1

\begin{tabular}{|c|l|c|c|c|c|c|}
\hline \multicolumn{2}{|c|}{ Maturity Level 1 } & \multirow{2}{*}{$\mathbf{0}$} & $\mathbf{0 . 3 3}$ & $\mathbf{0 . 6 6}$ & $\mathbf{1}$ & \\
\cline { 1 - 3 } No & \multicolumn{2}{|l|}{ Statement } & & \\
\cline { 1 - 5 } 1 & $\begin{array}{l}\text { an ad hoc } \\
\text { manner that }\end{array}$ & 8 & 5 & 2 & 3 & 5.97 \\
\hline
\end{tabular}




\begin{tabular}{|c|c|c|c|c|c|c|}
\hline \multicolumn{2}{|c|}{ Maturity Level 1} & \multirow{2}{*}{$\mathbf{0}$} & \multirow{2}{*}{0.33} & \multirow{2}{*}{0.66} & \multirow{2}{*}{1} & \\
\hline No & Statement & & & & & \\
\hline & $\begin{array}{l}\text { considered IT } \\
\text { risks }\end{array}$ & & & & & \\
\hline 2 & $\begin{array}{l}\text { each project } \\
\text { determines } \\
\text { assessments } \\
\text { of project risk }\end{array}$ & 9 & 4 & 2 & 3 & 5.64 \\
\hline 3 & $\begin{array}{l}\text { risk } \\
\text { assessments } \\
\text { are rarely } \\
\text { implemented } \\
\text { to specific } \\
\text { managers. }\end{array}$ & 4 & 7 & 2 & 5 & 8.63 \\
\hline 4 & $\begin{array}{l}\text { a project uses } \\
\text { risk } \\
\text { assessment } \\
\text { occasionally }\end{array}$ & 3 & 2 & 4 & 9 & 12.3 \\
\hline 5 & $\begin{array}{l}\text { management } \\
\text { meetings } \\
\text { seldom } \\
\text { discuss risk } \\
\text { assessment } \\
\end{array}$ & 11 & 3 & 1 & 3 & 4.65 \\
\hline 6 & $\begin{array}{l}\text { where risks } \\
\text { have been } \\
\text { considered, } \\
\text { mitigation is } \\
\text { inconsistent. }\end{array}$ & 6 & 3 & 2 & 7 & 9.31 \\
\hline 7 & $\begin{array}{lr}\text { It is are } \\
\text { essential to } \\
\text { understand IT } \\
\text { risks }\end{array}$ & & 4 & 1 & 13 & 14.98 \\
\hline & Total & & & & & 61.48 \\
\hline & Compliance $\mathrm{V}_{\mathrm{c}}$ & & & & & 8.78 \\
\hline
\end{tabular}

TABEL XII

COMPLIANCE LEVEL 2

\begin{tabular}{|c|c|c|c|c|c|c|}
\hline \multicolumn{2}{|c|}{ Maturity Level 2} & \multirow{2}{*}{$\mathbf{0}$} & \multirow{2}{*}{0.33} & \multirow{2}{*}{0.66} & \multirow{2}{*}{1} & \\
\hline No & Statement & & & & & \\
\hline 1 & $\begin{array}{l}\text { there is a risk } \\
\text { assessment by } \\
\text { project } \\
\text { managers }\end{array}$ & 2 & 2 & 2 & 12 & 13.98 \\
\hline 2 & $\begin{array}{ll}\text { only } & \text { to } \\
\text { significant } & \\
\text { projects or } \\
\text { response to } \\
\text { problems } \\
\text { applies the RA }\end{array}$ & 3 & 2 & & 13 & 13.66 \\
\hline 3 & $\begin{array}{l}\text { If there is a } \\
\text { risk only then } \\
\text { starting } \\
\text { mitigation } \\
\text { processes }\end{array}$ & 4 & 1 & 1 & 12 & 12.99 \\
\hline & \multicolumn{5}{|l|}{ Total } & 40.63 \\
\hline & \multicolumn{5}{|c|}{ Compliance Value } & 13.54 \\
\hline
\end{tabular}

TABEL XIII

COMPLIANCE LEVEl 3

\begin{tabular}{|c|c|c|c|c|c|c|}
\hline \multicolumn{2}{|c|}{ Maturity Level 3} & \multirow{2}{*}{$\mathbf{0}$} & \multirow{2}{*}{0.33} & \multirow{2}{*}{0.66} & \multirow{2}{*}{1} & \\
\hline No & Statement & & & & & \\
\hline 1 & $\begin{array}{l}\text { there is an } \\
\text { organization- } \\
\text { wide risk } \\
\text { management } \\
\text { policy. }\end{array}$ & 2 & 2 & 1 & 13 & 14.32 \\
\hline 2 & $\begin{array}{l}\text { there is risk } \\
\text { management } \\
\text { training is } \\
\text { available to all } \\
\text { staff } \\
\text { members. }\end{array}$ & 14 & 2 & & 2 & 2.66 \\
\hline 3 & $\begin{array}{l}\text { every } \\
\text { individual has } \\
\text { their own } \\
\text { decisions to } \\
\text { follow the risk } \\
\text { management } \\
\text { process and } \\
\text { receive } \\
\text { training. } \\
\end{array}$ & 15 & 2 & 1 & & 1.32 \\
\hline 4 & $\begin{array}{l}\text { the risk } \\
\text { assessment } \\
\text { ensures that } \\
\text { key risks to } \\
\text { the business } \\
\text { are identified. }\end{array}$ & 11 & 1 & 1 & 5 & 5.99 \\
\hline 5 & $\begin{array}{l}\text { once the risks } \\
\text { are identified, } \\
\text { then a process } \\
\text { to mitigate } \\
\text { key risks is } \\
\text { on. }\end{array}$ & 15 & 2 & 1 & & 1.32 \\
\hline 6 & $\begin{array}{l}\text { there is a job } \\
\text { description } \\
\text { that considers } \\
\text { risk } \\
\text { management } \\
\text { responsibilitie } \\
\text { s. }\end{array}$ & 4 & 4 & 2 & 8 & 10.64 \\
\hline & otal & & & & & 36.25 \\
\hline & Compliance Value & & & & & 6.04 \\
\hline
\end{tabular}

TABEL XIV

COMPLIANCE LEVEL 4

\begin{tabular}{|c|c|c|c|c|c|c|}
\hline \multicolumn{2}{|c|}{ Maturity Level 4} & \multirow[t]{2}{*}{ 0 } & \multirow{2}{*}{0.33} & \multirow{2}{*}{0.66} & \multirow[t]{2}{*}{1} & \\
\hline No & Statement & & & & & \\
\hline 1 & $\begin{array}{l}\text { the assessment } \\
\text { and management } \\
\text { of risk are } \\
\text { standard } \\
\text { procedures }\end{array}$ & & 2 & 1 & 15 & 16.32 \\
\hline 2 & $\begin{array}{l}\text { IT management } \\
\text { needs the risk } \\
\text { management } \\
\text { process } \\
\text { reporting. }\end{array}$ & & 6 & 1 & 11 & 13.64 \\
\hline
\end{tabular}




\begin{tabular}{|c|c|c|c|c|c|c|}
\hline \multicolumn{2}{|c|}{ Maturity Level 4} & \multirow[t]{2}{*}{$\mathbf{0}$} & \multirow[t]{2}{*}{0.33} & \multirow[t]{2}{*}{0.66} & \multirow[t]{2}{*}{1} & \\
\hline No & Statement & & & & & \\
\hline 3 & $\begin{array}{l}\text { IT risk } \\
\text { management is a } \\
\text { senior } \\
\text { management- } \\
\text { level } \\
\text { responsibility. }\end{array}$ & 3 & 2 & 1 & 12 & 13.32 \\
\hline 4 & $\begin{array}{l}\text { risk is assessed } \\
\text { and mitigated at } \\
\text { the individual } \\
\text { project level. }\end{array}$ & 1 & 4 & 7 & 6 & 11.94 \\
\hline 5 & $\begin{array}{l}\text { Management } \\
\text { receives advice } \\
\text { on changes in the } \\
\text { business and IT } \\
\text { environment that } \\
\text { could } \\
\text { significantly } \\
\text { affect the IT- } \\
\text { related risk } \\
\text { scenarios. }\end{array}$ & 9 & 3 & 2 & 4 & 6.31 \\
\hline 6 & $\begin{array}{l}\text { Management } \\
\text { monitors the risk } \\
\text { position }\end{array}$ & 3 & 5 & 2 & 8 & 10.97 \\
\hline 7 & $\begin{array}{l}\text { Top } \\
\text { management } \\
\text { (senior and IT } \\
\text { unit) establish } \\
\text { the firm RA will } \\
\text { put up with all } \\
\text { identified risks } \\
\text { have a } \\
\text { nominated. }\end{array}$ & & 1 & 2 & 15 & 16.65 \\
\hline 8 & $\begin{array}{l}\text { developing the } \\
\text { normal } \\
\text { management } \\
\text { based on RA and } \\
\text { RD }\end{array}$ & 1 & 2 & 1 & 14 & 15.32 \\
\hline 9 & $\begin{array}{l}\text { there is a } \\
\text { management } \\
\text { budget for an } \\
\text { operational risk }\end{array}$ & & 6 & 3 & 9 & 12.96 \\
\hline 10 & $\begin{array}{l}\text { there is a risk } \\
\text { assessment, and } \\
\text { management } \\
\text { processes are } \\
\text { starting to be } \\
\text { operated }\end{array}$ & 2 & 1 & 4 & 11 & 13.97 \\
\hline 11 & $\begin{array}{lr}\text { IT management } \\
\text { considers risk } \\
\text { mitigation } \\
\text { strategies. } \\
\end{array}$ & 1 & 4 & 4 & 9 & 12.96 \\
\hline & Total & & & & & $\begin{array}{c}144.3 \\
6\end{array}$ \\
\hline & Compliance Value & & & & & 13.12 \\
\hline
\end{tabular}

TABEL XV

COMPLIANCE LEVEL 5

\begin{tabular}{|c|c|c|c|c|c|c|}
\hline \multicolumn{2}{|c|}{ Maturity Level 5} & \multirow{2}{*}{ O } & \multirow{2}{*}{0.33} & \multirow{2}{*}{0.66} & \multirow{2}{*}{1} & \\
\hline No & Statement & & & & & \\
\hline 1 & $\begin{array}{l}\text { risk management } \\
\text { develops to the } \\
\text { stage } \\
\text { organization } \\
\text { well managed }\end{array}$ & 3 & 5 & 4 & 6 & 10.29 \\
\hline 2 & $\begin{array}{l}\text { acceptable risk } \\
\text { management } \\
\text { practices across } \\
\text { the entire } \\
\text { organization. }\end{array}$ & 8 & 6 & 1 & 3 & 5.64 \\
\hline 3 & $\begin{array}{l}\text { reporting of risk } \\
\text { management } \\
\text { data is highly } \\
\text { automated. }\end{array}$ & 7 & 3 & 2 & 6 & 8.31 \\
\hline 4 & $\begin{array}{l}\text { risk assessment } \\
\text { criteria based on } \\
\text { firm top } \\
\text { management in } \\
\text { the field }\end{array}$ & 3 & 4 & 2 & 9 & 11.64 \\
\hline 5 & $\begin{array}{l}\text { risk assessment } \\
\text { merges business } \\
\text { and IT system }\end{array}$ & 3 & 4 & 2 & 9 & 11.31 \\
\hline 6 & $\begin{array}{l}\text { Management } \\
\text { detects and acts } \\
\text { without } \\
\text { consideration of } \\
\text { the re risk } \\
\text { management } \\
\text { plan. }\end{array}$ & 9 & 4 & 2 & 3 & 5.64 \\
\hline 7 & $\begin{array}{lr}\text { Management } \\
\text { continues to } \\
\text { assess } \\
\text { mitigation } \\
\text { strategies. }\end{array}$ & 3 & 1 & 1 & 13 & 13.99 \\
\hline & & tal & & & & 6.82 \\
\hline & Compli & Ine & & & & .55 \\
\hline
\end{tabular}

TABEL XVI

MATURITY LEVEL OF ASSESS RISK

\begin{tabular}{|c|c|c|c|}
\hline \multicolumn{4}{|c|}{ PO9 maturity level calculation (level 0-5) } \\
\hline Level & Compliance & Normalize & Contribution \\
\hline 0 & 12.65 & 0.1986495 & 0 \\
\hline 1 & 8.78 & 0.1378769 & 0.137876884 \\
\hline 2 & 13.54 & 0.2126256 & 0.425251256 \\
\hline 3 & 6.04 & 0.0948492 & 0.284547739 \\
\hline 4 & 13.12 & 0.2060302 & 0.824120603 \\
\hline 5 & 9.55 & 0.1499686 & 0.749842965 \\
\hline & 63.68 & ML & 2.421639447 \\
\hline
\end{tabular}




\section{Discussion}

This research uses quantitative study analysis in literature review. Quantitative study analysis helps analyse through data processing approaches using statistical or mathematical methods [14], and the use of quantitative techniques also needs to pay attention to ethics in research analysis so that ethical quality is also maintained [15]. The respondent profile aims to describe the strength of research data that is trusted, accurate, and accountable [16]. Based on the reliability test, it shows if the questionnaire has a consistent quality of questions so that it can become a questionnaire as a measuring tool.

This research requires mapping to the COBIT 4.1 domain to describe the communication and control relationships in an IS development project [17]. One of the Domains in COBIT 4.1, namely the P09 Domains, helps analyse risk management [18]. Based on the maturity level test in risk management, it implies that the risk assessment process is still in the procedural stage. The resulting recommendation for VTMIS is the need for special training related to IT risk management in each process unit to provide an overview of how to mitigate IT risks.

Service becomes the first motto along with the development of information systems through service applications significantly affecting application development companies [13], [19]. The possibility of application errors in the system is very high related to risks in TI. A researcher said if the study of risk assessment methods to identify the presence of IT system sustainability aspects through the COBIT framework [20]. COBIT presents a detailed analysis of how organizations use this model [21]. This research through COBIT tries to check and analysis IT and firm risk to a good governance. This article also analyses the information based on the business and the scope of future research.

\section{CONCLUSION}

The maturity level of VTMIS risk management is 2.42 . The position level is at level 2, Repeatable but intuitive, meaning that the risk assessment process is still in the procedure stage. There is no specific training related to IT risks, and the possibility of application errors in the system is high risk in IT. The resulting recommendation for VTMIS is there needs to be special training related to IT risk management in each process unit to provide an overview of how to mitigate IT risks. Suggestions for further research with the object of IT risk management is to add monitor and evaluation domains as additional domains when researching so that monitoring and analysis can be more accurate.

\section{DAFTAR PUSTAKA}

[1] A. K. Tawalbeh and M. A. Niqresh, "The Role of Specialists in Improving the Quality of Government Institutions ' Information Documentation During COVID 19," Int. J. Contemp. Manag. Inf. Technol., vol. 1, no. 2, pp. 7-15, 2021.
[2] C. Chen, J. Ma, Y. Susilo, Y. Liu, and M. Wang, "The promises of big data and small data for travel behavior (aka human mobility) analysis," Transp. Res. Part C Emerg. Technol., vol. 68, pp. 285-299, 2016, doi: 10.1016/j.trc.2016.04.005.

[3] N. Poritskiy, F. Oliveira, and F. Almeida, "The benefits and challenges of general data protection regulation for the information technology sector," Digit. Policy, Regul. Gov., vol. 21, no. 5, pp 510-524, 2019, doi: 10.1108/DPRG-05-2019-0039.

[4] N. BATYASHE and T. IYAMU, "Operationalisation of the Information Technology strategy in an organisation," J. Contemp. Manag., vol. 17, no. 2, pp. 198-224, 2020, doi: $10.35683 / \mathrm{jcm} 20018.71$.

[5] L. Garicano and P. Heaton, "Information technology, organization, and productivity in the public sector: Evidence from police departments," J. Labor Econ., vol. 28, no. 1, pp. 167-201, 2010, doi: $10.1086 / 649844$

[6] M. Benaroch and A. Chernobai, "OPERATIONAL IT FAILURES, IT VALUE DESTRUCTION, AND BOARD-LEVEL IT GOVERNANCE CHANGES," MIS Q., vol. 41, no. 3, pp. 729-742, 2017, doi: 10.3109/10731199409117662.

[7] P. Durán Santomil and L. Otero González, "Enterprise risk management and Solvency II: the system of governance and the Own Risk and Solvency Assessment," J. Risk Financ., vol. 21, no. 4, pp. 317-332, 2020, doi: 10.1108/JRF-09-2019-0183.

[8] M. S. De Araujo, E. C. Oliveira, S. B. S. Monteiro, and T. M. F. De Queiroz Mendonça, "Risk management maturity evaluation artifact to enhance enterprise IT quality," ICEIS 2017 - Proc. 19th Int. Conf. Enterp. Inf. Syst., vol. 3, no. Iceis, pp. 425-432, 2017, doi 10.5220/0006324404250432.

[9] F. M. Alkhaldi, S. M. Hammami, and M. A. Uddin, "Understating value characteristics toward a robust IT governance application in private organizations using COBIT framework," Int. J. Eng. Bus. Manag., vol. 9, pp. 1-8, 2017, doi: 10.1177/1847979017703779.

[10] G. L. Lunardi, A. C. G. Maçada, J. L. Becker, and W. Van Grembergen, "Antecedents of IT governance effectiveness: An empirical examination in Brazilian firms," J. Inf. Syst., vol. 31, no. 1, pp. 41-57, 2017, doi: 10.2308/isys-51626

[11] M. El Khatib, L. Nakand, S. Almarzooqi, and A. Almarzooqi, "EGovernance in Project Management: Impact and Risks of Implementation," Am. J. Ind. Bus. Manag., vol. 10, no. 12, pp. 17851811, 2020, doi: 10.4236/ajibm.2020.1012111.

[12] D. Haouam, "IT governance impact on financial reporting quality using COBIT framework," Glob. J. Comput. Sci. Theory Res., vol. 10 no. 1, pp. 1-10, 2020, doi: 10.18844/gjcs.v10i1.4143.

[13] J. Aguiar, R. Pereira, J. B. Vasconcelos, and I. Bianchi, "An overlapless incident management maturity model for multiframework assessment (ITIL, COBIT, CMMI-SVC)," Interdiscip. J. Information, Knowledge, Manag., vol. 13, pp. 137-163, 2018, doi: $10.28945 / 4083$

[14] M. S. Rahman, "The Advantages and Disadvantages of Using Qualitative and Quantitative Approaches and Methods in Language 'Testing and Assessment' Research: A Literature Review," J. Educ. Learn., vol. 6, no. 1, p. 102, 2016, doi: 10.5539/jel.v6n1p102.

[15] M. J. Zyphur and D. C. Pierides, "Is Quantitative Research Ethical? Tools for Ethically Practicing, Evaluating, and Using Quantitative Research,” J. Bus. Ethics, vol. 143, no. 1, pp. 1-16, 2017, doi: 10.1007/s10551-017-3549-8

[16] A. Sturrock, A. Marsden, C. Adams, and J. Freed, "Observational and Reported Measures of Language and Pragmatics in Young People with Autism: A Comparison of Respondent Data and Gender Profiles," J. Autism Dev. Disord., vol. 50, no. 3, pp. 812-830, 2020, doi: 10.1007/s10803-019-04288-3.

[17] S. Gantman and J. Fedorowicz, "Communication and control in outsourced IS development projects: Mapping to COBIT domains," Int. J. Account. Inf. Syst, vol. 21, pp. 63-83, 2016, doi: 10.1016/j.accinf.2016.05.001

[18] J. F. Andry, G. Wang, G. N. Suryantara, and D. Y. Bernanda, "Assessing The COBIT Maturity Model in Manufacturing Company," Int. J. New Media Technol., vol. 5, no. 2, pp. 109-115, 2019, doi: 10.31937/ijnmt.v5i2.927 
[19] M. Jäntti and A. Cater-Steel, "Proactive Management of IT Operations to Improve IT Services," J. Inf. Syst. Technol. Manag., vol. 14, no. 2, pp. 191-218, 2017, doi: 10.4301/s1807-17752017000200004.

[20] P. Mulgund, P. Pahwa, and G. Chaudhari, "Strengthening IT Governance and Controls Using COBIT," Int. J. Risk Conting.
Manag., vol. 8, no. 10.4018/ijrcm.2019100104.

4, pp. 66-90, 2019, doi:

[21] Z. Alreemy, V. Chang, R. Walters, and G. Wills, "Critical success factors (CSFs) for information technology governance (ITG)," Int. J. Inf. Manage., vol. 36, no. 6, pp. 907-916, 2016, doi: 10.1016/j.ijinfomgt.2016.05.017. 